\title{
Origen y función de la argumentación: Pasos hacia una explicación evolutiva y cognitiva, de Cristián Santibáñez (2018), Palestra, 370 p.
}

DOI: 10.17230/co-herencia.17.32.12

\author{
Giohanny Olave* \\ olavearias@gmail.com
}

Dentro de la abundante bibliografía disponible en el campo de los estudios argumentativos, el libro del sociólogo y lingüista Cristián Santibáñez ofrece una perspectiva poco transitada en los estudios en español sobre el tema. Por medio de un enfoque evolutivo-cognitivo, Santibáñez responde en extenso a una pregunta esencial: “Por qué argumentamos?". Pese a que el autor augura que responder este interrogante puede llegar a impacientar a los teóricos clásicos de la argumentación, la contribución que realiza en esa área es invaluable, pues abre el campo explicativo hacia investigaciones interdisciplinares que va sugiriendo a lo largo del libro, a propósito de problemáticas difíciles, como las relaciones entre razonamiento y argumentación; las bases filogenéticas y la ontogénesis de la conducta argumentativa; la explicación acerca de las acciones e interacciones no cooperativas en los intercambios sociales; o el desarrollo de una base evaluativa que introduzca los estudios de la metáfora en las teorías de la argumentación, entre otras cuestiones estimulantes.

Argumentamos -propone el autor- porque evolucionamos sociocognitivamente hacia el esfuerzo por la cooperación y por la coordinación intencional colectiva. La argumentación, así, funciona como una competencia social desarrollada a lo largo de la serie evolutiva que permitió ampliar las posibilidades de supervivencia por medio de la resolución no violenta de las controversias. Funciona, además, como una estrategia o mecanismo de recursividad que permite anticiparse a las razones ajenas e, inclusive, comprenderlas empáticamente. En última instancia, la práctica argumentativa es

\footnotetext{
Doctor en Lingüística de la Universidad de Buenos Aires. Profesor de tiempo completo en la Universidad Industrial de Santander (UIS) e investigador Sénior de los grupos de investigación GLOTTA (UIS, categoría B de Colciencias) y Estudios del Lenguaje y la Educación (Universidad Tecnológica de Pereira, Colombia). ORCID: 0000-0001-6794-6472
} 
el producto del desarrollo de ambientes colectivistas de interacción que presionaron para estructurar un diseño mental que se adaptó a la preferencia por el intercambio de razones. Esta "tecnología cognitiva" se caracteriza por beneficiar -inmediata o eventualmente- a todos los actores que, genuinamente, se esfuerzan por argumentar; una tecnología que solo pudo aparecer después de suplir las necesidades básicas y transitar hacia las necesidades simbólicas: el acuerdo, el consenso, la inteligencia social, la cooperación, la explotación de fuentes informativas o productivas, etcétera. Así lo sintetiza el autor:

La argumentación funciona como una facultad a través de la que se establecen las creencias y otros estados intencionales contextuales que son mutuamente beneficiosos (para todos los miembros de un grupo), así como una competencia que coordina la toma de decisiones sobre los nuevos cursos de acción de un agente o individuo (Santibáñez, 2018, p. 106).

Los cambios producidos por ambos tipos de acción están regidos por mecanismos cognitivos y sociales cooperativos ("una presión selectiva para comunicar buenas razones", p. 107) que se activan cuando aparecen disrupciones o amenazas a la coordinación colectiva.

El cuerpo central del libro contiene diez capítulos organizados en tres partes: en la primera ("Las razones fundamentales de la evolución de la argumentación”), se da cuenta de las bases sociales de la argumentación como facultad o mecanismo evolutivo cultural, principalmente para defender la naturaleza normativa del acto de argumentar y las habilidades que demuestran la plasticidad cerebral a favor del desarrollo de la vida en sociedad.

En la segunda parte del libro ("Trazados filogenéticos y ontogenéticos de la destreza cognitiva de argumentar") se detalla la infraestructura inferencial de la facultad argumentativa por medio de su rastreo analógico en primates e infantes, para lo cual se revisa la noción de protoargumentación y su fuerte dependencia de la especificidad de las relaciones sociales dentro de las que aparece.

En la parte final, el libro ofrece una interesante discusión de los argumentos de la Teoría argumentativa del razonamiento (Mercier \& Sperber, 2017) y de los conceptos de la vigilancia epistémica y del sesgo de confirmación. Santibáñez discute el desplazamiento de la cooperación como eje central de la actividad argumentativa, tal como lo realizan los autores que comenta cuando sostienen que los 
humanos no optan por el esfuerzo argumentativo interaccional, sino por la justificación de sus conclusiones previas a la discusión racional, por medio del argumento menos demandante desde el punto de vista cognitivo. A esta perspectiva el autor opone el diseño recursivo de la facultad argumentativa ("Yo sé que él sabe que yo evalúo sus razones"), que permite lidiar con la variedad de los contenidos informativos en las interacciones, orientarlos y darles funcionalidad dentro de la estructura argumental de la lógica práctica (Toulmin, 1958).

La discusión anterior, que retoma el modelo toulminiano y lo ilumina desde el punto de vista evolutivo-cognitivo, se traslada al examen de la metáfora conceptual en la cognición social y el rol que desempeña en algunas interacciones argumentativas. Dentro de la misma parte final del libro, se abordan dos problemas más que formarían parte de lo que el autor denomina "manifestaciones de la destreza cognitiva de argumentar": las interacciones argumentativas no cooperativas y una aproximación al campo de la argumentación visual. En el primer caso, el autor concluye que, pese a existir los engaños, autoengaños, mentiras y manipulaciones, la evidencia evolutiva devela que las conductas egoístas no logran superponerse a la preferencia por la honestidad estratégica en términos grupales. Finalmente, en cuanto a la argumentación por medio de imágenes, se revisan algunas teorías contemporáneas semióticas y cognitivas que el autor propone articular con el modelo toulminiano y con las nociones de cognición distribuida y extendida. Estas últimas, relacionadas con la argumentación en general y con la visual en particular, también representarían una estrategia evolutiva colectivista, en la medida en que dependen y activan parámetros culturales al servicio de jerarquías de creencias.

En suma, las tres partes conforman una obra teórica sólida, con "pasos" en firme hacia una explicación evolutivo-cognitiva de la argumentación. Como lo resalta el mismo autor al final de las conclusiones, hay una apuesta fuerte por la cooperación como tendencia en la evolución cognitiva y cultural humana. Esa apuesta deriva en una confianza excesiva en la buena fe, la autorregulación y la racionalización de los actores involucrados en disputas verbales, inclusive cuando son álgidas y están atravesadas por factores externos determinantes, como la mediatización. Asimismo, el enfoque 
cooperativo puede explicar también la casi nula atención de esta propuesta explicativa a la dimensión pasional (tímica) presente en los intercambios argumentativos, y a la equivalencia discutible entre la argumentación como actividad evaluativa (esencial a la interacción argumentativa) y como actividad normativa (no esencial).

Pese a estos aspectos y a que la lectura del libro es exigente, por el abundante despliegue de referencias en estos campos disciplinares y en las teorías de la argumentación, el autor se preocupa por explicar con paciencia los referentes, enfatizar en las ideas centrales y destacar las discusiones que propone. En estas últimas reside el principal aporte de la obra y transparenta la valiosa trayectoria investigativa del profesor Santibáñez en los estudios de la argumentación 【

\section{Referencias}

Mercier, H. \& Sperber, D. (2017). The Enigma of Reason: A New Theory of Human Understanding. Allen Lane.

Toulmin, S. (1958). The Uses of Argument. Cambridge University Press. 